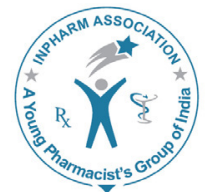

\title{
Antioxidant Ability of Some Common Indian Vegetables
}

\author{
Kumkum Agarwal ${ }^{1 *}$, Ranjana Varma ${ }^{2}$ \\ ${ }^{1}$ Research Scholar, Department of Botany, Sarojini Naidu Govt. Girls P.G. College, Shivaji Nagar, \\ Bhopal-462016, Madhya Pradesh, India. \\ ${ }^{2}$ Professor, Department of Botany, Sarojini Naidu Govt. Girls P.G. College, Shivaji Nagar, Bhopal-462016, \\ Madhya Pradesh, India
}

\begin{abstract}
Objective: The aim of this research work is to investigate antioxidant ability and analyse phytochemicals in some of the common Indian vegetables. Methodology: Different concentrations of the extracts were screened for estimating their DPPH scavenging ability by UV-spectrophotometry. Methanol was used as control while ascorbic acid was used as a standard antioxidant. IC50 and percentage inhibition were calculated. Results: Chenopodium album was found to show higher ability with $\mathrm{IC}_{50}$ at $82.93 \pm 0.17 \mu \mathrm{g} / \mathrm{ml}$ while maximum \% inhibition of $68.74 \pm 0.17 \%$ was obtained at $100 \mu \mathrm{g} / \mathrm{ml}$. The $\mathrm{R}^{2}$ values were greater than 0.9 indicating that the relationship between extract concentration and \% inhibition was extremely strong. Qualitative biochemical analysis of both the extracts showed the presence of carbohydrates, reducing sugars, alkaloids, flavonoids, triterpenoids, steroids, tannin and phenolic compound. Conclusions: The in vitro study showed that Portulaca oleracea and Chenopodium album proved to be good scavengers of free radicals like DPPH.
\end{abstract}

Key words: DPPH scavenging, $I_{50}$, In vitro, Qualitative analysis, $\mathrm{R}^{2}$ values, UV-spectrophotometry.

Key message: The two commonly eaten vegetables has shown potent antioxidant activity, thus it could be suggested for use in oxidative stress related diseases and can be eaten normally for prevention. Thus this article justifies the importance of vegetables and their use in traditional medicines for curing various diseases. Literature survey has shown that DPPH scavenging potential in methanolic extract of whole plant of Chenopodium album was not found to be reported in earlier studies.

\section{INTRODUCTION}

Oxidative stress is the imbalance between the production of reactive oxygen species and the antioxidant defense molecules present in the living system i.e. when the former exceeds the latter. Antioxidants are substances that either delay or inhibit the oxidation of molecules like lipids by inhibiting the initiation or propagation of oxidative

\begin{tabular}{|c|c|}
\hline \multicolumn{2}{|c|}{ Access this article online } \\
\hline Journal Sponsor & \multirow[b]{2}{*}{$\begin{array}{l}\text { Website: } \\
\text { www.jyoungpharm.org }\end{array}$} \\
\hline \multirow{2}{*}{ www.phcog net } & \\
\hline & $\begin{array}{l}\text { DOI: } \\
\text { 10.5530/jyp.2015.3.18 }\end{array}$ \\
\hline
\end{tabular}

chain reactions thus, preventing and repairing the damage caused by the reactive oxygen species to various cells. ${ }^{1}$ The various enzymatic components include glutathione peroxidase, catalase (CAT) and superoxide dismutase (SOD), etc., while the non-enzymatic antioxidants can be phenolic compounds, nitrogenous compounds, carotenoids, vitamins including ascorbic acid, vitamin $\mathrm{E}$ and b-carotene etc. ${ }^{2} \mathrm{~A}$ freshly prepared DPPH solution exhibits a deep purple color with absorption maximum at $517 \mathrm{~nm}$. The purple color fades when an antioxidant is present in the medium and results are reported as $\mathrm{IC}_{50}$. Antioxidant activity in Portulaca oleracea ${ }^{3-5}$ and Chenopodium album $^{5}$ has been reported by various workers. In this piece of research work the DPPH scavenging ability and the

\footnotetext{
*Address for correspondence:

Miss. Kumkum Agarwal, Research Scholar, Department of Botany, Sarojini Naidu Govt. Girls P.G. College, Shivaji Nagar, Bhopal-462016, Madhya Pradesh, India.E-mail : atharva72013@gmail.com
} 


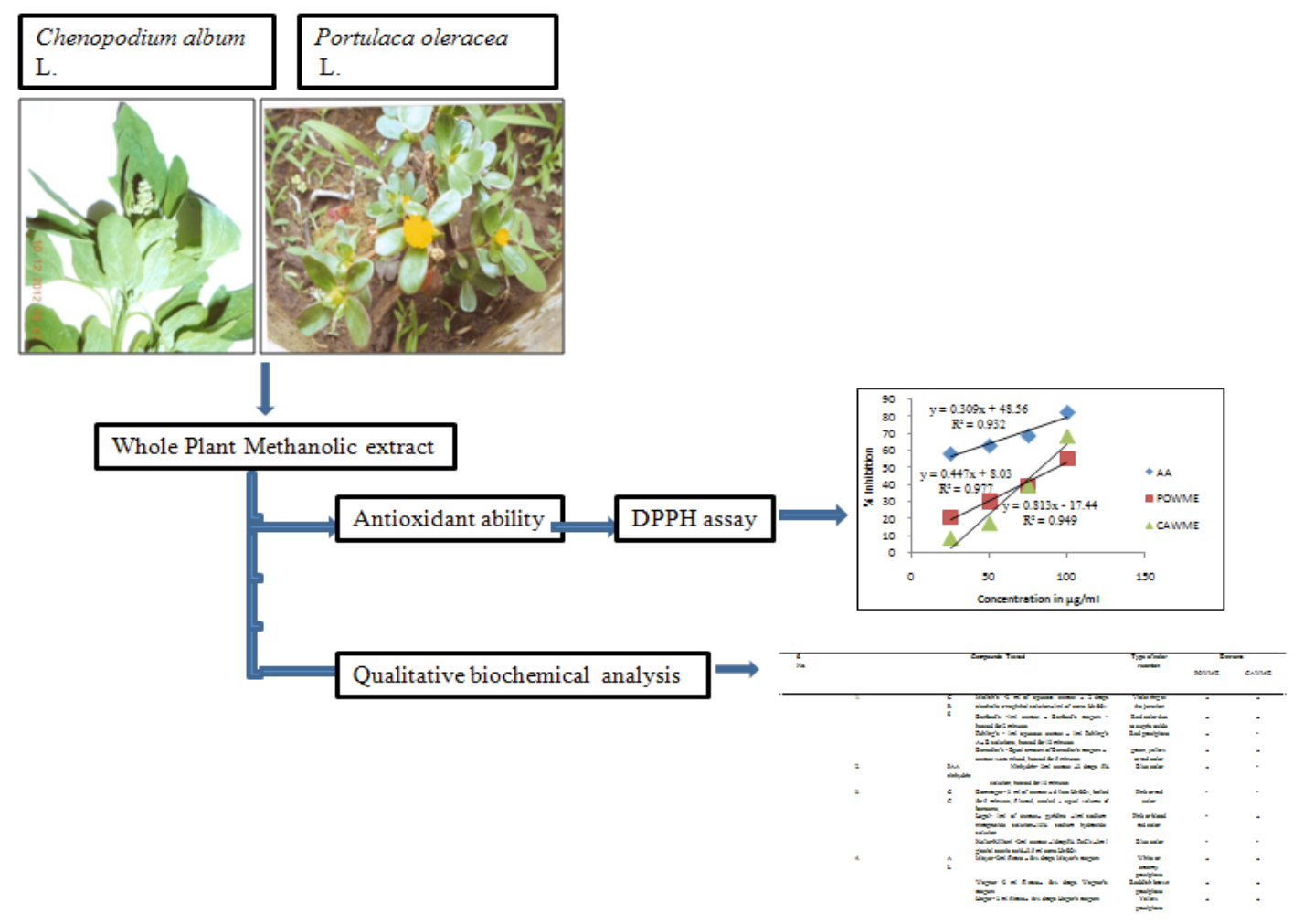

Graphical Abstract

qualitative phytochemical analysis of both these vegetables was undertaken.

\section{MATERIALS AND METHODS}

All chemicals used were of high purity Merck grade. DPPH was purchased from Sigma Aldrich. The whole plant of Portulaca oleracea and Chenopodium album were procured from Vitthal market, Bhopal during the months of May and November, 2012 respectively. The plants were identified with the help of the herbarium of Botanical Survey of India (BSI), Allahabad, with voucher specimen numbers1114-23.01-52 and 1310-131.01-648 respectively. Fresh plant was shade dried and grinded then it was extracted with alcohol by Soxhlet apparatus for 72 hours and concentrated in vacuum to dryness at $30-40^{\circ} \mathrm{C}$ temperature, obtaining dried extract.

\section{Experimental Work}

DPPH radical scavenging assay

In this procedure UV-spectrophotometric (Systronics spectrophotometer 166) determination of antioxidant ability by DPPH assay ${ }^{6}$ was undertaken. Methanol was used as the solvent for preparing different solutions (25-100 $\mu \mathrm{g} / \mathrm{ml}$ ) of ascorbic acid and plant extracts (25-200 $\mu \mathrm{g} /$ $\mathrm{ml})$ and as control.
To $1.5 \mathrm{ml}$ of each of the solutions of standard, test and control, $1.5 \mathrm{ml}$ of $200 \mu \mathrm{M}$ DPPH solution was mixed and incubated for 30 minutes. Absorbance of each was read at $517 \mathrm{~nm}^{7-9}$

Percentage of antioxidant activity was calculated as:

$$
I \%=\frac{A c-(A t-A b)}{A c} \times 100
$$

Where, $\mathrm{I} \%=$ Percentage inhibition, $A c=$ Absorbance of control, At=Absorbance of sample with DPPH solution, $\mathrm{Ab}=$ Absorbance of sample without DPPH solution.

Qual itative Biochemical analysis

Qualitative biochemical analysis of the two extracts was undertaken by using standard procedures. ${ }^{7-10}$

Carbohydrates \& Reducing Sugars (CRS)

Molish, barfoed's, fehling's and benedicts tests were applied. ${ }^{9,10}$

Proteins and amino acids (PAA)

Ninhydrin test was applied., ${ }^{910}$ 
Glycosides (GC)

Borntrager's, legal's and keller-killiani test were applied., ${ }^{9,10}$

Alkaloids (AL)

To the extract, add dilute $\mathrm{HCl}$ then shake and filter it. With this filtrate standard mayer's, wagner's and hager's tests were performed. ${ }^{9,10}$

Flavonoids (FN)

Alkaline reagent, shinoda and lead acetate tests were applied. ${ }^{9,10}$

Saponin (SN)

Foam test was applied. ${ }^{9,10}$

Triterpenoids and Steroids (TS)

Salkowski's and libermann-burchard's tests were applied., ${ }^{9,10}$

Tannin and Phenolic compounds (TPC)

Ferric chloride, lead acetate, dilute iodine solution tests were applied. ${ }^{9,10}$

\section{Statistical analysis}

In statistical analysis of results regression was calculated for knowing the relationship among variables (through excel) using regression equation: $y=a+b x$, Where $y=$ estimated $\mathrm{y}$ value for given $\mathrm{x}$ value, $\mathrm{a}=$ intercept on the $\mathrm{y}$ axis, $\mathrm{b}=$ the slope (the average change in y for each change of 1 unit in $\mathrm{x}), \mathrm{R}^{2}=$ Correlation coefficient.

\section{RESULTS}

In the present piece of research work DPPH assay was utilized to estimate the antioxidant ability of both the plant extracts. The results for ascorbic acid which was used as a standard reference compound were the same as mentioned in our previous research papers ${ }^{7-9}$ i.e. it showed lowest $\mathrm{IC}_{50}$ value of $4.69 \pm 0.02 \mu \mathrm{g} / \mathrm{ml}$ as well as it showed the highest inhibition of $82.05 \pm 0.12 \%$ at 100 $\mu \mathrm{g} / \mathrm{ml}$ concentration while lowest inhibition of $58.18 \pm$ $0.17 \%$ was obtained at $25 \mu \mathrm{g} / \mathrm{ml}$ concentration. When comparing both the methanolic whole plant extracts, the extract of Portulaca oleracea showed $\mathrm{IC}_{50}$ value at 93.89 $\pm 0.08 \mu \mathrm{g} / \mathrm{ml}$ concentration. Maximum inhibition of $54.85 \pm 0.08 \%$ was obtained at $100 \mu \mathrm{g} / \mathrm{ml}$. The $\mathrm{R}^{2}$ value obtained from the regression curve was 0.977 . The extract of Chenopodium album showed $\mathrm{IC}_{50}$ value at $82.93 \pm 0.17$ $\mu \mathrm{g} / \mathrm{ml}$ concentrations. Maximum inhibition of $68.74 \pm$ $0.17 \%$ was obtained at $100 \mu \mathrm{g} / \mathrm{ml}$. The $\mathrm{R}^{2}$ value obtained from the regression curve was 0.949 (Figure 1). In both these extracts the $\mathrm{R}^{2}$ values were greater than 0.9 indicating that the relationship between extract concentration and $\%$ inhibition was extremely strong. Qualitative biochemical analysis of both the methanolic plant extracts showed the presence of carbohydrates, reducing sugars, alkaloids, flavonoids, triterpenoids, steroids, tannin and phenolic compound while proteins and amino acids were only present in Portulaca oleracea and glycosides were only found to be present in Chenopodium album (Table 1).

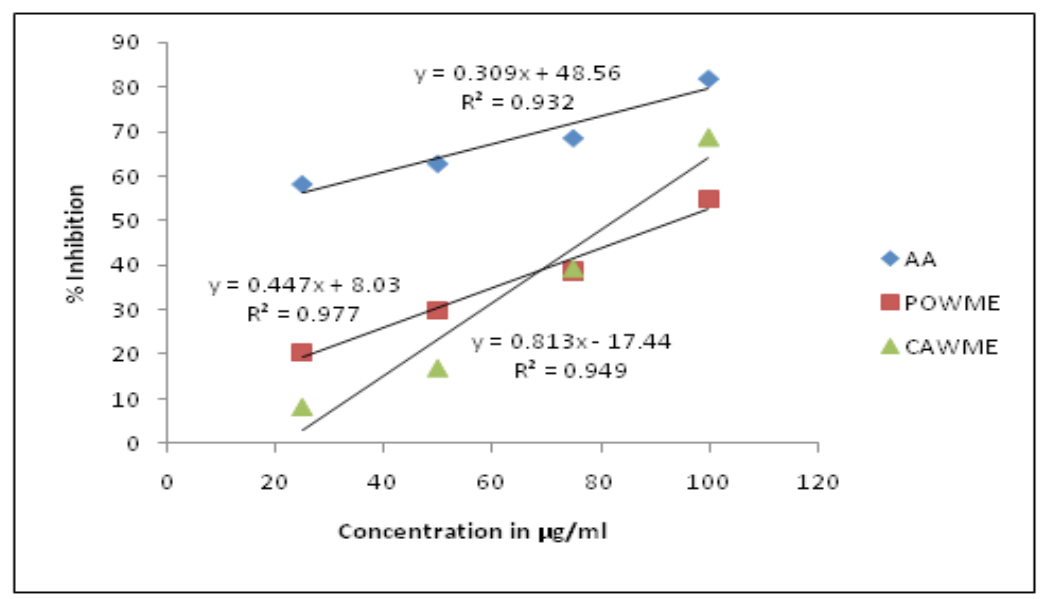

Figure 1: Regression curve of standard and plant extracts representing the $D P P H$ inhibiting ability

AA-Ascorbic acid, POWME: Portulaca oleracea whole plant methanolic extract; CAWME: Chenopodium album whole plant methanolic extract, DPPH-1,1, diphenyl2 picrylhydrazyl 
Table 1: Qualitative analysis of biochemicals in plant extracts

\begin{tabular}{|c|c|c|c|c|}
\hline \multirow{2}{*}{\multicolumn{2}{|c|}{$\begin{array}{l}\text { Compounds } \\
\text { Tested }\end{array}$}} & \multirow{2}{*}{ Type of color reaction } & \multicolumn{2}{|c|}{ Extracts } \\
\hline & & & POWME & CAWME \\
\hline \multirow{4}{*}{ CRS } & $\begin{array}{c}\text { Molish's }-2 \text { ml of aqueous extract }+2 \text { drops alcoholic } \\
\alpha \text {-naphthol solution }+1 \text { ml of conc. } \mathrm{H}_{2} \mathrm{SO}_{4}\end{array}$ & Violet ring at the junction & + & + \\
\hline & $\begin{array}{l}\text { Barfoed's-1mlextract+Barfoed's reagent-heated for } \\
\qquad 2 \text { minutes }\end{array}$ & Red color due to cupric oxide & + & + \\
\hline & $\begin{array}{l}\text { Fehling's - } 1 \text { ml aqueous extract }+1 \text { ml Fehling's } A+B \\
\text { solutions, heated for } 10 \text { minutes }\end{array}$ & Red precipitate & + & - \\
\hline & $\begin{array}{l}\text { Benedict's-Equal amount of Benedict's reagent + } \\
\text { extract were mixed, heated for } 5 \text { minutes }\end{array}$ & green, yellow or red color & + & + \\
\hline PAA & $\begin{array}{c}\text { Ninhydrin- } 3 \text { ml extract }+3 \text { drops } 5 \% \text { ninhydrin solution, } \\
\text { heated for } 10 \text { minutes }\end{array}$ & Blue color & + & - \\
\hline \multirow{3}{*}{ GC } & $\begin{array}{l}\text { Borntrager- } 3 \mathrm{ml} \mathrm{of} \mathrm{extract}+\text { dilute } \mathrm{H}_{2} \mathrm{SO}_{4} \text {, boiled for } 5 \\
\text { minutes, filtered, cooled + equal volume of benzene, }\end{array}$ & Pink or red color & - & - \\
\hline & $\begin{array}{l}\text { Legal- } 1 \text { ml of extract+ pyridine }+1 \mathrm{ml} \text { sodium } \\
\text { nitropruside solution }+10 \% \text { sodium hydroxide solution }\end{array}$ & Pink or blood red color & - & + \\
\hline & $\begin{array}{c}\text { Keller-Killiani- } 2 \mathrm{ml} \text { extract+1 drop5 } \% \mathrm{FeCl}_{3}+3 \mathrm{ml} \text { glacial } \\
\text { acetic acid+0.5 ml conc. } \mathrm{H}_{2} \mathrm{SO}_{4}\end{array}$ & Blue color & - & - \\
\hline \multirow{3}{*}{ AL } & Mayer -2 ml filtrate + few drops Mayer's reagent & White or creamy precipitate & + & + \\
\hline & Wagner-2 ml filtrate+few drops Wagner's reagent & Reddish brown precipitate & + & + \\
\hline & Hager-2 ml filtrate+few drops Hager’s reagent & Yellow precipitate & + & + \\
\hline \multirow{3}{*}{ FN } & Alkaline reagent test-extract +few drops $\mathrm{NaOH}$ & yellow color & + & + \\
\hline & $\begin{array}{l}\text { Shinoda- extract }+5 \text { ml ethanol }+ \text { few fragments of } \\
\text { magnesium turning }+ \text { conc. } \mathrm{HCl}\end{array}$ & Pinkcolor & + & + \\
\hline & Lead acetate-extract+few drops lead acetate solution & Yellow precipitate & + & + \\
\hline SN & Foam - extract + distilled water, shaken & Foamylayer & - & - \\
\hline \multirow[b]{2}{*}{ TS } & $\begin{array}{l}\text { Salwonski-extract+chloroform, filtered+few drops } \\
\text { conc. } \mathrm{H}_{2} \mathrm{SO}_{4} \text {, shaken }\end{array}$ & $\begin{array}{l}\text { Lower layers turn red (sterols } \\
\text { present) or golden yellow } \\
\text { (triterpenes present) }\end{array}$ & + & + \\
\hline & $\begin{array}{l}\text { Liberman and Burchards-extract+chloroform+acetic } \\
\text { anhydride, boiled, cooled +conc. } \mathrm{H}_{2} \mathrm{SO}_{4}\end{array}$ & $\begin{array}{l}\text { Two layers formed, upper } \\
\text { layer turns green (steroids } \\
\text { present) or deep red } \\
\text { (triterpenoids present). }\end{array}$ & + & + \\
\hline \multirow{3}{*}{ TPC } & $\begin{array}{l}\text { Ferric chloride -extract }+ \text { distilled water }+2 \mathrm{ml} \text { of } 5 \% \\
\qquad \mathrm{FeCl}_{3}\end{array}$ & Blue, green orviolet color & + & + \\
\hline & $\begin{array}{l}\text { Lead acetate-extract + distilled water + lead acetate } \\
\text { solution }\end{array}$ & White precipitate & + & + \\
\hline & $\begin{array}{l}\text { Dilute lodine solution }-2 \text { ml extract solution+ few drops } \\
\text { dilute iodine solution }\end{array}$ & Transient red color & + & + \\
\hline
\end{tabular}

POWME: Portulaca oleracea whole plant methanolic extract; CAWME: Chenopodium albumwhole plant methanolic extract; + Present, - Absent; CRS: Carbohydrates \& Reducing Sugars; PAA: Proteins \& amino acids; GC: Glycosides; AL: Alkaloids; FN: Flavonoids; SN: Saponin; TS: Triterpenoids and Steroids; TPC: Tannin and Phenolic compounds, $\mathrm{H}_{2} \mathrm{SO}_{4}$ : Sulphuric acid, $\mathrm{HCl}$-Hydrochloric acid, $\mathrm{FeCl}_{3}$-ferric chloride, $\mathrm{NaOH}$-Sodium hydroxide.

\section{DISCUSSION}

These vegetables after in vivo tests can be recommended for consumption in oxidative stress related diseases. Chenopodium album was found to show lower $\mathrm{IC}_{50}$ value alongwith higher percentage of inhibition. Although several researchers ${ }^{10}$ have reported antioxidant potential in its leaves but to the best of our knowledge and in accordance with the literature review DPPH scavenging potential in methanolic extract of whole plant of Chenopodium album was not found to be reported in earlier studies.

The antioxidant activity of alkaloids ${ }^{11}$ flavonoids ${ }^{12}$ phenolic compounds, saponins, ${ }^{13}$ glycosides,${ }^{14}$ proteins,${ }^{15}$ tannins,${ }^{16}$ triterpenoids ${ }^{17}$ and steroids ${ }^{18}$ has been reported. Thus, the presence of these phytochemicals in both the extracts indicate towards the positive relation between these phytochemicals with their antioxidant potential.

\section{CONCLUSION}

This in vitro study showed that both plants are good scavengers of free radicals like DPPH and when used as vegetables or in medicines they will be beneficial for treating various oxidative stress related diseases. These in vitro results should be confirmed in vivo. 


\section{CONFLICT OF INTEREST}

Authors declared there is no conflict of interest.

\section{ACKNOWLEDGEMENTS}

The author would like to acknowledge the Principal of Sarojini Naidu Govt. Girls. P.G. College, Bhopal as well as sincere gratitude are also due to the Head of Department of Botany, Teaching and non-teaching staff of the college for their cooperation.

\section{Highlights of Paper}

- Reactive oxygen species (ROS) are considered responsible for causing various diseases.

- Antioxidants prevent and repair the damage caused by ROS.

- Both Portulaca oleracea and Chenopodium album showed antioxidant ability but the latter was found to be more potent antioxidant.

- In both these extracts the $\mathrm{R}^{2}$ values were greater than 0.9 indicating that the relationship between extract concentration and $\%$ inhibition was extremely strong.

- Qualitative biochemical analysis showed the presence of biochemicals that are known to have antioxidant ability.

\section{Author Profile}

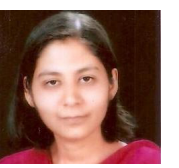

- Kumkum Agarwal is a Research Scholar in the Department of Botany, Sarojini Naidu Govt.Girls P.G. (Auto.) College Bhopal India. Her research interest is to study various aspects of medicinal plants, including their ethnobotanical and taxonomical studies, in vitro medicinal abilities including antioxidant and calcium oxalate inhibiting ability as well as their phytochemical analysis.

\section{REFERENCES}

1. Cadenas E, Packer L. Hand book of antioxidants, $2^{\text {nd }}$ ed.USA: Marcel Dekker AG Publication; 2002. p. 10-5.

2. Sharma $P$, Jha A, Dubey R, Mohammad P. Reactive oxygen species, oxidative damage, and antioxidative defense mechanism in plants under stressful conditions. Journal Botany 2012; 20(2012): 1-27.

3. Oliveira I, Valentao P, Lopes R, Andrade P, Bento A, Pereira J. Phytochemical characterization and radical scavenging activity of Portulaca oleracea L. leaves and stems. Microchemical J. 2009; 92(2): 129-34

4. Dkhill M, Moniem A, Quraishy S, Saleh R. Antioxidant effect of purslane (Portulaca oleracea) and its mechanism of action. J. Med. Plants Res. 2011; 5(9): 1589-63.

5. Ghimire B, Seong E, Kim E, Ghimeray A, Yu C, Ghimire B, et al. A comparative evaluation of the antioxidant activity of some medicinal plants popularly used in Nepal. J Med Plants Res. 2011; 5(10): 1884-91.

6. Pandey N, Barve D. Antioxidant activity of ethanolic extract of Annona squamosa L. bark'. International Journal Research Pharmaceutical Biomedical Sciences 2011; 2(4): 1692-97.

7. Kumkum A, Ranjana V. Studies on antioxidant activity and phytochemical screening of selected medicinal plant Ocimum gratissimum L. International Journal Pharmaceutical Sciences Research 2014; 5(8): 1000-8.

8. Kumkum A, Ranjana V. Reactive oxygen species scavenging ability and phytochemical screening of an asteraceae member-Xanthium strumarium. Int J Pharm Phytopharmacol Res. 2014; 3(4): 306-10.

9. Kumkum A, Ranjana V. Antioxidant activity and phytochemical analysis of Hyptis suaveolens (L.) Poit. J Adv Pharm Edu Res.
2013; 3(4): 541-9.

10. Gokhale S, Kokate C, Purohit A. Pharmacognosy, India. Nirali Prakashan; 2006. p. 22-5.

11. Olarte E, Herrera A, Villasenor I, Jacinto S. Antioxidant activity of a new indole alkaloid from Cassia alata L. Philipp Agric Scientist 2010; 93(3): 250-4.

12. Singh D, Chander V, Chopra K. Protective effect of catechin on ischemia reperfusion induced renal injury in rats. Pharmacol Rep. 2005; 57(1): 70-6.

13. Gulcin I, Mshivdadze V, Gepdiremen A. Antioxidant activity of saponins isolated from ivy: alpha hederin, hederasaponin-C, hederacolchiside-E and hederacolchiside-F. Planta Med. 2004; 70(6): 561-3.

14. Pujimulyani D, Raharjo S, Marsono $Y$. The effect of blanching on antioxidant activity and glycosides of white saffron (Curcuma mangga Val.). International Food Research Journal 2012; 19(2): 617-21.

15. Elias R, Kellerby S, Dekker E. Antioxidant activity of proteins and peptides. Crit Rev Food Sci Nutr. 2008; 48(5): 430- 41.

16. Zhang S, Lin Y, Zhou H, Wei S, Lin G, Ye G. Antioxidant tannins from stem bark and fine root of Casuarina equisetifolia. Molecules 2010; 15(8): 5658-70.

17. Arafat $O$, Tham S, Sadikun A, Zhari I, Haughton P, Asmawi M. Studies on diuretic and hypouricemic effects of Orthosiphon stamineus methanol extracts in rats. J Ethnopharmacol. 2008; 118(3): 354-60.

18. Mooradian A. Antioxidant properties of steroids. J Steroid Biochem Mol Biol. 1993; 45(6): 509-11. 